Provided for non-commercial research and education use. Not for reproduction, distribution or commercial use.

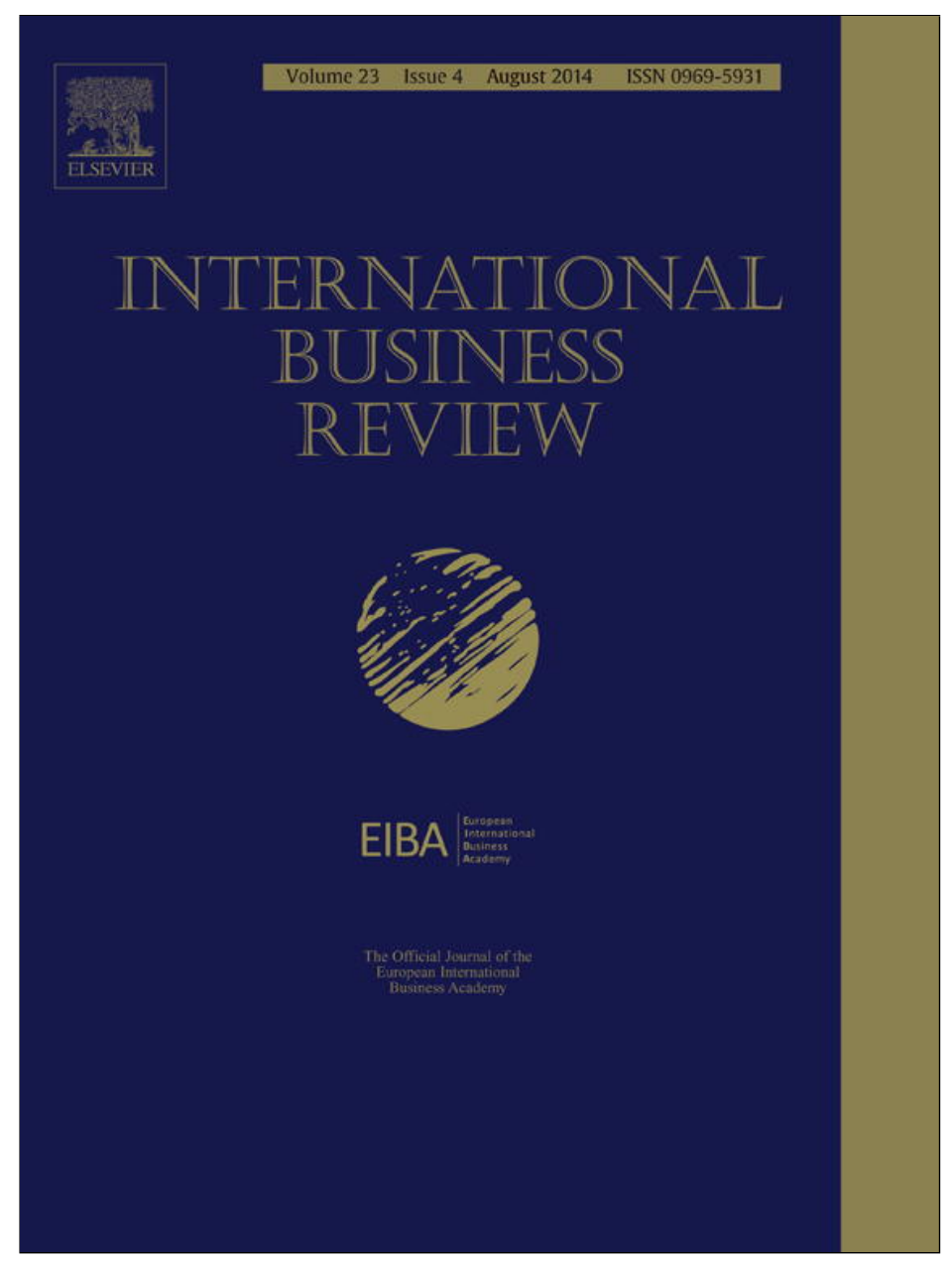

This article appeared in a journal published by Elsevier. The attached copy is furnished to the author for internal non-commercial research and education use, including for instruction at the authors institution and sharing with colleagues.

Other uses, including reproduction and distribution, or selling or licensing copies, or posting to personal, institutional or third party websites are prohibited.

In most cases authors are permitted to post their version of the article (e.g. in Word or Tex form) to their personal website or institutional repository. Authors requiring further information regarding Elsevier's archiving and manuscript policies are encouraged to visit:

http://www.elsevier.com/authorsrights 


\title{
Economic slowdowns, hazard rates and foreign ownership
}

\author{
Celeste Varum $^{\mathrm{a}, *}$, Vera Catarina Rocha ${ }^{\mathrm{b}, 1}$, Hélder Valente da Silva ${ }^{\mathrm{c}, 1}$ \\ ${ }^{a}$ Department of Economics, Management and Industrial Engineering, GOVCOPP, University of Aveiro, 3810-193 Aveiro, Portugal \\ ${ }^{\mathrm{b}}$ Department of Economics, Management and Industrial Engineering, University of Aveiro, 3810-193 Aveiro, Portugal \\ ${ }^{\mathrm{C}}$ Faculty of Economics of University of Porto, Rua Dr. Roberto Frias, 4200-464 Porto, Portugal
}

\section{A R T I C L E INFO}

\section{Article history:}

Received 2 July 2012

Received in revised form 29 August 2013

Accepted 25 November 2013

Available online 15 December 2013

\section{JEL classification:}

D21

F23

L25

L60

Keywords:

Economic slowdowns

Foreign ownership

Hazard rates

Manufacturing

Portugal

\begin{abstract}
A B S T R A C T
This paper evaluates the link between foreign ownership and firm exit during crises, using a longitudinal micro dataset over an 18-year period. We address two main questions: first, if foreign affiliates have different failure rates than domestic firms during economic downturns, and second if the foreignness effect differs between two different economic downturns. The results partially confirm the liability of foreignness argument, suggesting that when the crisis was more pronounced at home than abroad, the differences in hazard rates between foreign and domestic firms reduce. The footloose argument is also only partially confirmed. For policy makers, our results on survival dynamics during crises are not against policies stimulating inward investment. There is no need to fear that foreign firms destabilize more than usual the host economy during economic slowdowns by immediately closing down operations.
\end{abstract}

(๖ 2013 Elsevier Ltd. All rights reserved.

\section{Introduction}

The recent global financial and economic crisis and the consequent scaling up of bankruptcy indicators call for further reflection on the survival patterns of firms during a crisis period. The literature on firm survival has shown the detrimental impact of macroeconomic instability upon firms' survival and their dynamics (e.g., Audretsch \& Acs, 1994; Bhattacharjee, Higson, Holly, \& Kattuman, 2009; Geroski, Mata, \& Portugal, 2010; Varum \& Rocha, 2011, 2012). However, particular groups of firms may be better able to surpass the difficulties of a crisis. In this regard, one may ask if foreign firms exit with less or greater likelihood than their domestic counterparts, and how does this likelihood of exiting vary in economic downturns. This issue has been relatively neglected in the literature, albeit the weight of foreign firms on many host economies.

There is a rich stream of literature investigating the survival of firms in foreign markets in comparison with domestic firms (Bernard \& Sjöholm, 2003; Görg \& Strobl, 2003a, 2003b; Kronborg

\footnotetext{
* Corresponding author. Tel.: +351 234370 200x23633; fax: +351 234370215 . E-mail addresses: camorim@ua.pt (C. Varum), verarocha@ua.pt (V.C. Rocha), hmvs@fep.up.pt (H. Valente da Silva).

${ }^{1}$ Tel.: +351234370 200x23633; fax: +351234370215
}

\& Thomsen, 2009; Li \& Guisinger, 1991; Mata \& Portugal, 2002). The overwhelming conclusion is that after controlling for characteristics that make foreign firms different than domestic ones, foreign firms tend to exit with greater likelihood. The most common explanations to why foreign firms exit more often than domestic ones rest upon the idea that in host economies foreign firms face certain disadvantages vis-à-vis their domestic counterparts, thus suffering from a 'liability of foreignness' (Zaheer, 1995). Along this line of thought, the theory of multinational enterprises has developed upon the argument that firms operating in foreign markets need to have some type of ownership advantages to compensate for these increased costs of doing business abroad (Dunning \& Lundan, 2008). From another line of argumentation, multinationals are by nature more footloose than domestic firms, and therefore are more likely to exit (Mata \& Freitas, 2012).

Both lines of argument support the view that foreign firms may be more likely to exit markets. However, they lead to different expectations with respect to the likelihood of exit during economic downturns. The footloose argument implies that foreign firms should be even more likely to exit during downturns. When changes in the host economy make that economy less attractive, relocation is seen more favorably by foreign firms than by domestic ones, which are more attached to a particular location. Alternatively, the liability of foreignness argument implies that the exit rates of foreign and domestic firms should converge during 
Table 1

Empirical evidence on the foreign ownership-firm survival link. ${ }^{a}$

\begin{tabular}{ll}
\hline (A) Positive relationship & (B) Negative relationship \\
\hline Behrman and Deolalikar (1989) - Indonesia [1975-1985] & Zaheer and Mosakowski (1997) - 47 countries [1974-1993] \\
Li and Guisinger (1991) - USA [1978-1988] & Görg and Strobl (2003a, 2003b) - Ireland [1973-1996] \\
Audretsch and Mahmood (1994) - USA [1976-1986] & Bernard and Sjöholm (2003) - Indonesia [1975-1989] \\
Mata and Portugal (2004) - Portugal [1983-1989] & Bimura and Kiyota (2006) - Japan [1994-2000] \\
Narjoko and Hill (2007) - Indonesia [1993-2000] & Vernard and Jensen (2007) - USA [1987-1997] Beveren (2007) - Belgium [1996-2001] \\
Bridges and Guariglia (2008) - UK [1997-2002] & Fertala (2008) - Germany [1997-2004] \\
Girma and Gong (2008) - China [1999-2005] & Allvarez and Görg (2009) - Chile [1990-2000] \\
Kronborg and Thomsen (2009) - Denmark [1895-2005] & Bandick and Görg (2010) - Sweden [1993-2002] \\
Holmes, Hunt, and Stone (2010) - UK [1973-2001] & Kimura and Kiyota (2007) - Japan [1994-1998] \\
(C) Neutral relationship & Taymaz and Özler (2007) - Turkey [1983-2001]
\end{tabular}

a Studies are presented in a chronological order (Reference - Country [Time Period]).

downturns because foreign firms hold some sort of ownership advantages over domestic ones. Foreign multinationals may have better conditions to face the crises owing to their multinationality advantages or they may resist more due to the sunk costs associated with their investment (Chung, Lu, \& Beamish, 2008; Desai, Foley, \& Forbes, 2004; Ghosal, 2010).

Studies about the importance of foreign ownership during crises are relatively scarce, the notable exceptions being the studies by Álvarez and Görg (2009), Lee and Makhija (2009) and Varum and Rocha (2011). Hence, in this paper we use longitudinal firm-level data for a large time span to assess, first, whether foreign ownership contributes to differentiating the incidence of firm exit during crises, controlling for other determinants that may affect the exit risk of firms. We use discrete time hazard models that account for firm-level unobserved heterogeneity to answer our research questions. In addition, we analyze whether the foreign ownership effect differs between two crises, which occurred in the same economy, in different periods of time and with different characteristics. To our knowledge the paper is unique in these respects. We analyze manufacturing firms created in Portugal in the period 1988-2005 by following their paths during the whole period and the economic slowdowns of early 1990s and 2000s. Portugal in particular is an interesting case as the economy experienced these significant slowdowns which provide us with 'a natural experiment to identify directly the "footloose nature" of multinationals' (Álvarez \& Görg, 2009).

Results from past lessons may be of value in understanding more modern recessions, such as the one from which the world economy is currently recovering. For the Portuguese case we add to the previous important contributions of Mata and Portugal (2002, 2004), by enlarging the time span of their study and focusing on the potential effect of foreign ownership during (different) downturn periods. Compared to Varum and Rocha (2011), who examined the link between foreign ownership, firm employment and turnover growth and crises, the present study investigates firms' dynamics in terms of firm survival, using discrete time duration models. The analysis also adds to Varum and Rocha (2012) by exploring the foreignness effect upon firm survival under crises, differentiating between two distinct crisis contexts.

The paper is organized as follows. Section 2 reviews the literature on foreign ownership-firm survival relationship. Most of this literature does not focus on the effects during downturns, but allows for understanding why we may expect differences between foreign and domestic firms' exits patterns. Section 3 relates to methodological issues, where the data and econometric procedures are outlined. Section 4 presents some descriptive statistics and discusses the results. Section 5 concludes.

\section{Macroeconomic conditions, foreign ownership, firm survival and exit}

The overall state of the economy has long been indicated as an important force driving firms out of business (Geroski et al., 2010). Current macroeconomic environment affects not only market conditions but also market expectations about the future, leading firms to exit if an unfavorable environment is predictable. Despite the fact that some studies prove that exit is not responsive to the cycle (e.g. Boeri \& Bellman, 1995; Ilmakunnas \& Topi, 1999), many others found that firm exit is countercyclical and that there is a detrimental impact of macroeconomic instability upon firms' survival and their dynamics (Audretsch \& Acs, 1994; Bhattacharjee et al., 2009; Box, 2008; Varum \& Rocha, 2012). Downturn periods are expected to increase firms' hazards, though eventually this effect may be different between firms. Hence, it is important to investigate which firm-level conditions contribute to explain why firms resist differently during economic slowdowns.

Many studies have investigated the survival of firms in foreign markets. The empirical results on this matter are not unanimous (see Table 1). The overwhelming conclusion is that when controlling for a number of variables along which foreign firms differentiate from domestic ones, the former often exhibit higher exit rates. This fact may be due to the liability of foreignness (Zaheer \& Mosakowski, 1997) or to the footloose nature of multinationals.

However, it remains overlooked whether under a crisis' environment foreign firms are affected or react differently from domestic firms and, if that is the case, whether or not their advantages compensate for the disadvantages of doing business abroad, possibly making them weather the crisis in a better way (or not). From the literature, we may explore arguments for a stabilizer or otherwise role of multinational enterprises (MNEs) during economic downturns.

\subsection{Footloose multinationals and economic downturns}

Compared to their domestic counterparts, it may be easier for foreign firms to transfer production facilities internationally (Flamm, 1984; Lee \& Makhija, 2009), to cut operational costs (Gao \& Eshaghoff, 2004) and, in the extreme, to exit the local economy. If multinationals are indeed more "footloose", they may be expected to be more likely to leave the country, especially during that period when it is hit by a negative shock. Actually, and relying on the way of thinking about foreign direct investment (FDI) enriched by real option theory (Campa, 1993; Li \& Rugman, 2007), foreign firms may decide to switch operations quickly between locations in response to changing costs differentials, market opportunities and host country uncertainty, particularly 
when the "growth-or-switch options" created when investing abroad overlap or duplicate each other (Belderbos \& Zou, 2009). Unless sunk costs and the irreversibility of investment are considerable - which may, in opposition, create some "hysteresis" and inertia in foreign firms' strategic response to macroeconomic changes - multinational firms tend to be more footloose than their domestic counterparts when facing environmental uncertainty, especially when their real investment options are redundant, either at the host-country level or at the MNE portfolio level (Belderbos \& Zou, 2007, 2009; Ghosal, 2010; Lehmann, 2002).

Though empirical analyses on MNEs' responses to macroeconomic changes are still scant, some results already emerged. Using plant-level data for manufacturing industries in Chile, Álvarez and Görg (2009) examined the determinants of exit probabilities of plants in the period 1995-2000 covering a major slowdown in the late 1990s, paying particular attention to the role of the nationality of the plant. They found robust evidence that foreign plants were more likely to exit only for the late 1990s, when the Chilean economy was in recession. They argue that this evidence is consistent with the argument that multinationals are more likely to readjust their investment decisions and exit if the economy is hit by a negative shock. Hence, following this line of argumentation, we derive the following hypothesis:

Hypothesis 1. The probability of exit of foreign-owned firms increases even further to those of domestic firms during economic downturns.

\subsection{Liability of foreignness and ownership advantages over economic downturns}

The liability of foreignness (Zaheer, 1995), or the extra costs foreign firms face vis-à-vis their domestic counterparts in host economies, has been at the center of the literature that found foreign firms to exit more than domestic ones with similar characteristics (Bernard \& Sjöholm, 2003; Görg \& Strobl, 2003a, 2003b; Zaheer \& Mosakowski, 1997). Even though, foreign enterprises are said to possess firm-specific advantages - of the type described in the pioneering work of Hymer (1976) - that compensate for the liability of foreignness, which make them able to surpass and to outperform their domestic counterparts in the host economy (Dunning \& Lundan, 2008). These advantages may become more valuable during economic downturns in the host economy.

Chung et al.'s (2008) study of a sample of Japanese subsidiaries from 1994 to 1999 indicates that the enhanced flexibility associated with intra- and inter-firm organizational linkages is more likely to increase the performance of subsidiaries operating in a crisis rather than in economically stable environments. Blalock, Gertler, and Levine (2005), in turn, investigated whether foreign ownership affected investment in Indonesia in 1997 following the Asian financial crisis. Despite they could not reject somewhat higher excess mortality rates among foreign-owned plants, they concluded that the post-crisis excess mortality of foreign firms was lower than the differences found in the pre-crisis. They argued that this convergence was due to the 'multinationality' advantage of foreign firms. Firms with foreign ownership, in particular those more oriented toward export markets, could access credit through their parent company and thus insure themselves against liquidity constraints. Accordingly, foreign subsidiaries in MNE networks may survive longer in a crisis owing to their better access to resources and greater ability to use internal capital markets when faced with financial constraints, being able to access overseas credit through their parent companies, which allows them to expand their economic activity even in turbulent periods (e.g., Desai et al., 2004). The argumentation above predicts that during economic downturns, the incidence of the exit of foreign firms, which in normal periods tends to be higher, may actually get closer to that of domestic firms. Hence, we derive the following alternative hypothesis:

Hypothesis 2. The probability of exit of foreign owned firms becomes closer to that of domestic firms during economic downturns.

In what follows we conduct the empirical analysis and derive our conclusions of the aforementioned hypotheses.

\section{Data and methodological issues}

\subsection{Data}

In this study, we use data from Quadros de Pessoal (henceforth QP), a matched employer-employee administrative dataset from the Portuguese Ministry of Employment. QP is an annual mandatory employment survey that all firms in the private sector employing at least one wage earner are legally obliged to fill in. Requested data cover the establishment (location, employment and economic activity), the firm (location, employment, sales, economic activity, ownership, number of establishments and legal setting) and each of its workers (gender, age, education, qualifications, occupational category, employment status, earnings, tenure and hours of work). All firms, establishments and workers entering QP dataset have a unique identification number, so we can track firms/establishments and workers over time and match workers with their respective employers. This makes QP a suitable dataset to study firm survival and exit.

We have access to the original data for the period 1985-2007. By working directly with raw data files at the firm-level, it was possible to compute entry and exit measures by ourselves. Firm's entry year corresponds to the first year the firm appears in the dataset. Therefore, we can only identify entries from 1986 onwards, as data for 1985 was only used to check the presence of firms in the dataset. The time of exit, in turn, was determined by the last year the firm was registered in QP. However, as temporary exits of one year may occur (for instance, due to a firm's delay in delivering the survey in a particular year), we have required an absence of the firm from QP for at least two consecutive years to confirm that the firm has definitely exited and closed operations. Accordingly, we can identify exits only until 2005, as data for 2006 and 2007 are only used to check the records of the firm in the two subsequent years.

Firm exit is defined as the event of closing a firm. Despite the comprehensiveness of the QP database, it has also some limitations, which prevented us from distinguishing between different exit modes - namely between voluntary exit and bankruptcy - or even from identifying cases in which a firm is absorbed or taken over by another firm. The same problems were already faced by previous empirical works for Portugal (e.g. Geroski et al., 2010; Mata \& Portugal, 2002, 2004) using QP data. As a result, our analysis is based on the timing at which a firm ceases to do business, disappearing from QP records. Regarding possible cases of mergers, in which an independent legal unit might disappear without the corresponding disappearance of the firm, there is no published data on mergers for Portugal. However, Geroski et al. (2010) ensure that less than $1 \%$ of the total number of liquidations in Portugal is due to mergers or acquisitions, which suggests that our limitations in identifying exits due to mergers have no significant impact on our results.

The analysis is performed for firms operating in Manufacturing Industry during the period 1988-2005. We have to restrict the period to 1988-2005 because we only have data on the industry's 
exports and imports (which are needed to compute industry's openness to trade, to be controlled in our estimations) from 1988 onwards (see Appendix A.I). We focus on the 1988 and later cohorts, following each firm since the year of entry until its last record in the database, which may correspond to the moment of exit or, alternatively, to the last year we have information about the firm. If the firm has not experienced the exit during the whole period, it is identified as a right-censored case, corresponding to firms whose entry year is known but which are still active when the period under study ends (Hosmer, Lemeshow, \& May, 2008; Singer \& Willett, 1993).

\subsection{Empirical strategy and variables}

We rely on duration models, which provide a dynamic framework that addresses the inability of static binary choice models to take into account right-censoring issues. As data on firms' duration comes from an annual survey, our measured durations are grouped into yearly time intervals, which are properly accommodated by discrete time duration models (Singer \& Willett, 1993). We thus proceed by dividing the time axis (1988-2005) into 18 intervals, corresponding to our 18 measured durations.

Formally, we observe firm $i$ 's spell from period $j=1$ (corresponding to the year of entry) through to the end of the $j$ th period, at which point $i$ 's spell is either complete $c_{i}=1$ or right-censored $c_{i}=0$ (flow sample). To estimate the discrete interval hazard rate that is, the probability of exiting at discrete time $t_{j}, j=1,2, \ldots$, conditional upon having survived until then - can be defined as:

$h_{i j}=\operatorname{Pr}\left(T_{i}=j \mid T_{i} \geq j\right)=F\left(\gamma(t)+X_{i}^{\prime}(t) \beta+\varepsilon_{i}\right)$,

where $h_{i j}$ is the probability of firm $i$ remaining active for exactly $j$ years; $\gamma(t)$ describes the pattern of duration dependence (the baseline hazard); $X_{i}^{\prime}(t)$ is a vector of firm and industry-level variables which, from the literature, and similarly to Varum and Rocha (2012), are expected to impact on firm survival (see Appendix A.I for details on these variables); $\beta$ is a vector of unknown parameters to be estimated; $\varepsilon_{i}$ is a disturbance term that includes the time-invariant unobserved heterogeneity (the firmspecific effect) and that is assumed to be uncorrelated with the observable firm and industry characteristics $X_{i}^{\prime}(t)$; and finally $F(\cdot)$ denotes the complementary log-logistic distribution function.

Following prior studies on firm survival using QP (Mata \& Portugal, 2002; Varum \& Rocha, 2012), we do not impose any functional form for $\gamma(t)$; we instead estimate a piecewise constant hazard model, where exit rates are assumed to be constant within each interval (year) but different between intervals (years). Thus, in order to estimate the full set of $\gamma$ 's, we have added an indicator variable per duration time $t$ to the model. This flexible modeling has been recognized to be preferred in order to avoid serious misspecifications. Moreover, such hazard formulation with a flexible baseline hazard function makes an attractive model with which to combine a specific heterogeneity assumption (Cameron \& Trivedi, 2005: 620). Accordingly, following usual conventions (e.g., Hougaard, 1995; Jenkins, 2005), we assume an Inverse Gaussian distribution for the unobserved heterogeneity term, so that $\varepsilon_{i}$ is normally distributed with zero mean and unitary variance.

Summing up, the discrete time hazard function in (1), to be estimated under a complementary log-logistic model with Inverse Gaussian unobserved heterogeneity, may be rewritten as follows:

$h_{i j}=1-\exp \left\{-\exp \left[\gamma(t)+X_{i}^{\prime}(t) \beta+\log \left(\varepsilon_{i}\right)\right]\right\}$.

The variable Foreign Ownership - one of the core variables included in the vector $X_{i}^{\prime}(t)$ - will allow us to assess the effect of foreign capital participation in firms' exit patterns. As our main goal is to assess whether foreign-owned firms have different failure rates than domestic firms during downturns, and if that effect differs depending on the type of crises, we focus our attention on an interaction term between Foreign Ownership and two indicator variables for the periods of economic downturn (For. Own*Downturn $_{i}$, with $\left.i=1991-1994,2001-2003\right)$.

Regarding other firm and industry-level variables that are believed to affect firm survival, we follow the existent empirical literature on firm survival determinants (see, for instance, ManjónAntolín and Arauzo-Carod (2008) for a survey). At the firm-level, we control for firm age (see Jovanovic, 1982; Stinchcombe, 1965, among others), firm size (measured by the log number of employees) (e.g., Varum \& Rocha, 2012), human capital (proxied by the share of college workers) (e.g., Acs \& Armington, 2009; Bates, 1990), firm performance (sales per worker, in logs) (e.g., Bandick, 2010; Carreira \& Teixeira, 2011) and location in urban centers (e.g., Fotopoulos \& Louri, 2000). The effects of firm age and size are allowed to be non-linear in line with most of the literature, as these variables may exert an increasing (decreasing) effect on firm exit risks up to some point of firm age or size, while exerting a decreasing (increasing) effect thereafter.

Concerning the industry environment, we will control for potential differences in the industry context. We will consider the minimum efficient scale - calculated as the median of 2-digit industry's employment - as one of the reasons why so many firms fail is that their entry size is smaller than the minimum scale required to be efficient (Audretsch, 1995). By including industry openness (measured by the ratio of 2-digit industry's (export$\mathrm{s}+$ imports) to industry's gross value added), we try to take the industry's exposure to international conditions into account. We will control for market concentration through the HerfindahlHirschman $(\mathrm{HH})$ Index, which may either raise the risk of failure through greater competition intensity or decrease the exit rates by offering the incumbents enough power to retaliate against entrants. Industry growth (in terms of employment) will also be controlled for, as average profits are affected by growth rates of industries, so industries growing quickly may exert positive impacts upon survival. Entry rates may also be associated with firm survival, as firms tend to enter the industries where higher profits are expected. Agglomeration economies at the industry and regional-levels, as well as foreign presence in the industry, will also be taken into account, as they are commonly controlled for in comparative studies of domestic and foreign firms (see Table A.I for additional details on the computation of these variables). Regarding foreign presence, this variable is commonly introduced in firm survival studies, not only to try to capture horizontal spillovers from multinationals to other firms in the industry (Álvarez \& Görg, 2009), but also in order to account for some unobserved characteristics of the industries, such as advertising and technological intensity (Mata \& Portugal, 2002), which may be related to the previous presence of foreign firms in the market.

\section{Empirical results}

\subsection{Descriptive statistics and unconditional survival analysis}

\subsubsection{Survival and hazard rates}

Over the time period under scrutiny, it was possible to identify two downturn periods in the Portuguese economy: the early 1990s (1991-1994) and the early 2000s (2001-2003) (Bank of Portugal, 2009). Figs. 1 and 2 illustrate, respectively, the evolution of real GDP growth rates and unemployment rates over the period under study, both for Portugal and for the Euro area. In these periods, the common stylized facts for a downturn period were observed - both periods were characterized by declines in GDP growth rates, in private consumption and investment and by a rise in unemployment. However, the early 2000s recession was different from that 


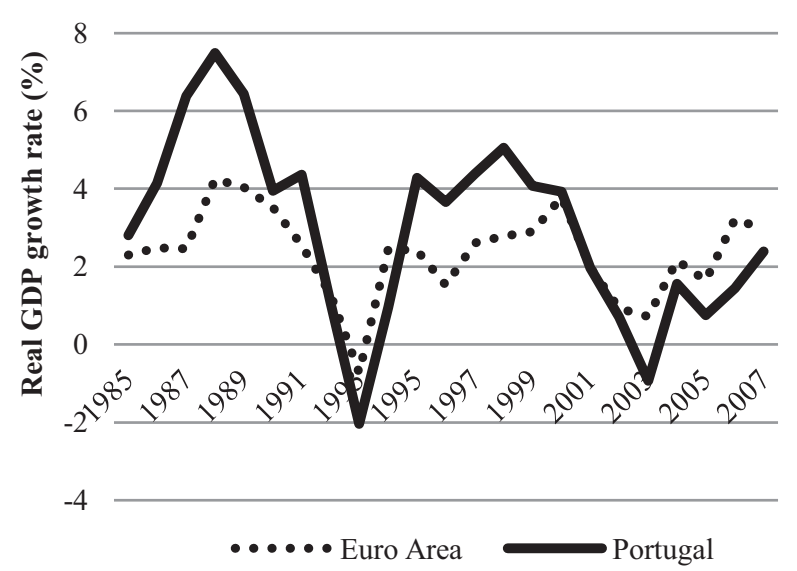

Fig. 1. Annual growth rate of real GDP.

Source: World Development Indicators.

occurred in 1993/1994, when foreign demand for goods fell 3.2\%, which culminated into a period of several years in which there was a gradual slowing of this variable. According to the Bank of Portugal (2004), the reduction of the product in 2003 was not associated with a fall in exports of goods and services. Hence, for the purpose of our analysis we consider the second crisis to be predominantly domestic driven.

After identifying entry and exits of firms in Manufacturing, we obtained a discrete time panel data set composed by 87,027 firms "born" during the period 1988-2005. From these, 55,622 exits were identified. As a first step of our survival analysis, we have estimated the survivor function of firms, without controlling for any observed and unobserved differences between them. Using Kaplan-Meier (KM) estimator (Kalbfleisch \& Prentice, 1980), the unconditional probability of a firm surviving beyond time $t$ is computed as follows:

$\hat{S}\left(t_{j}\right)=\prod_{j=t_{0}}^{t}\left(1-\frac{d_{j}}{n_{j}}\right)$

where $d_{j}$ is the number of exits in each time interval and $n_{j}$ is the number of firms at risk of exit. Precise estimations for the survivor and hazard functions for all firms are presented in Table 2.

Only $15.57 \%$ of the firms remained active after 18 years. The results also confirm the high exit rate of young firms. Indeed, the risk of exit tends to be higher during the first five years of
14

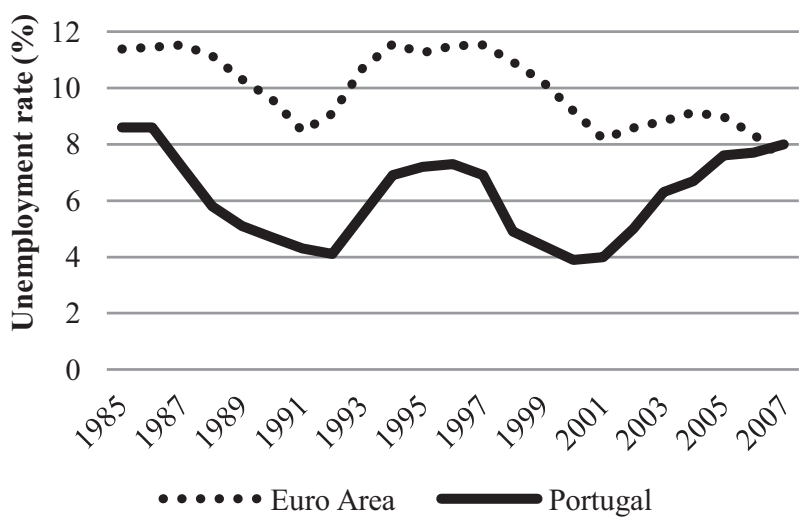

Fig. 2. Unemployment rate.

activity - which corresponds to the estimated median survival time - being slightly lower thereafter. In particular, data show that more than $50 \%$ of firms ceased their operations during the first five years and almost $70 \%$ of firms exited before completing a decade of activity.

Fig. 3 depicts the KM survivor functions for different categories of firms, stratified according to their foreign ownership status (Domestic Firm if less than 10\% of the capital is held by foreigners, Minority Foreign Firm (FF) if the share of foreign capital is between $10 \%$ and $49 \%$, Majority FF if this share is between $50 \%$ and $99 \%$ and, finally, Wholly-Owned FF for the cases in which $100 \%$ of the capital is foreign). Table 3 compares the unconditional survival rates between small and large firms within the samples of foreign and domestic firms. Firms are stratified into small and medium-sized or large-sized firms through an indicator variable Small that assumes the value 1 if the firm is a SME (Small-Medium Enterprise). This classification is made according to the European definition of SMEs (European Commission, 2005).

Unconditionally, foreign-owned firms survive longer than their domestic counterparts and, moreover, wholly foreign-owned firms seem to have the highest survival rates. Median survival time is lower for domestic firms (about four to five years against 10-12 years for foreign firms). The Log-Rank and Wilcoxon tests confirm that differences are statistically significant at the $1 \%$ level. Taking in consideration firm size, the differences in survival chances seem not to be relevant among foreign firms. Conversely, large domestic

Table 2

Survival and hazard rates - all firms in Portuguese manufacturing industry, 1988-2005.

\begin{tabular}{|c|c|c|c|c|c|c|c|c|}
\hline Time interval & Nr. firms at risk & Nr. failures & Net Lost $\mathrm{t}^{\mathrm{a}}$ & Survival & Std. error & Hazard & Std. error & Cumulative failure \\
\hline$[1-2[$ & 87,027 & 16,890 & 3350 & 0.8059 & 0.0013 & 0.1941 & 0.0015 & 0.1941 \\
\hline$[2-3[$ & 66,787 & 9631 & 2820 & 0.6897 & 0.0016 & 0.1442 & 0.0015 & 0.3103 \\
\hline$[3-4[$ & 54,336 & 7058 & 3145 & 0.6001 & 0.0017 & 0.1299 & 0.0015 & 0.3999 \\
\hline$[4-5[$ & 44,133 & 5328 & 3381 & 0.5277 & 0.0018 & 0.1207 & 0.0017 & 0.4723 \\
\hline [5-6[ & 35,424 & 3953 & 3466 & 0.4688 & 0.0018 & 0.1116 & 0.0018 & 0.5312 \\
\hline$[6-7[$ & 28,005 & 2872 & 1975 & 0.4207 & 0.0018 & 0.1026 & 0.0019 & 0.5793 \\
\hline$[7-8[$ & 23,158 & 2277 & 1544 & 0.3793 & 0.0018 & 0.0983 & 0.0021 & 0.6207 \\
\hline$[8-9[$ & 19,337 & 1704 & 1335 & 0.3459 & 0.0018 & 0.0881 & 0.0021 & 0.6541 \\
\hline$[9-10[$ & 16,298 & 1387 & 1290 & 0.3165 & 0.0019 & 0.0851 & 0.0023 & 0.6835 \\
\hline$[10-11[$ & 13,621 & 1125 & 1060 & 0.2903 & 0.0019 & 0.0826 & 0.0025 & 0.7097 \\
\hline$[11-12[$ & 11,436 & 929 & 1273 & 0.2668 & 0.0019 & 0.0812 & 0.0027 & 0.7332 \\
\hline [12-13[ & 9234 & 787 & 1491 & 0.2440 & 0.0019 & 0.0852 & 0.0030 & 0.7560 \\
\hline [13-14[ & 6956 & 547 & 896 & 0.2248 & 0.0019 & 0.0786 & 0.0034 & 0.7752 \\
\hline [14-15[ & 5513 & 447 & 854 & 0.2066 & 0.0019 & 0.0811 & 0.0038 & 0.7934 \\
\hline [15-16[ & 4212 & 303 & 950 & 0.1917 & 0.0020 & 0.0719 & 0.0041 & 0.8083 \\
\hline [16-17[ & 2959 & 181 & 855 & 0.1800 & 0.0020 & 0.0612 & 0.0045 & 0.8200 \\
\hline [17-18[ & 1923 & 150 & 914 & 0.1660 & 0.0022 & 0.0780 & 0.0064 & 0.8340 \\
\hline [18-19[ & 859 & 53 & 806 & 0.1557 & 0.0025 & 0.0617 & 0.0085 & 0.8443 \\
\hline
\end{tabular}

a "Net Lost" gives the number of censored cases, and hence the cases no longer entering the risk set. 


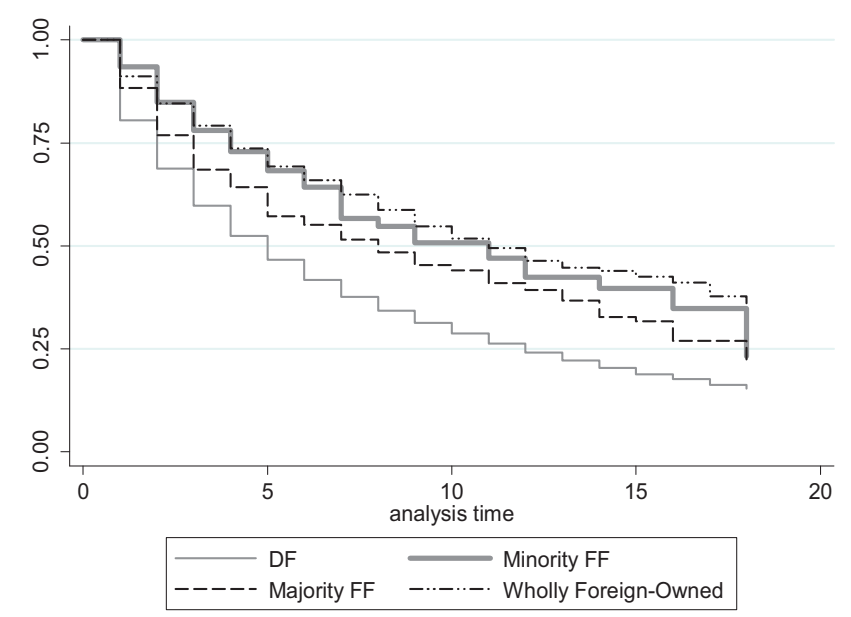

Log-Rank Test $\chi^{2}(3)=228.53 * * *$ Wilcoxon Test $\chi^{2}(3)=207.41^{* * *}$

Fig. 3. K-M survivor function, by foreign ownership.

firms seem to have substantially better chances of survival. In opposition, small domestic firms are more exposed to risk of exit during their infancy, with almost $40 \%$ of these firms closing down operations before the third year of activity, and less than $50 \%$ reaching the fifth year.

\subsubsection{Describing foreign and domestic firms}

Table 4 provides a brief comparison between domestic and foreign firms, presenting the mean values of the main independent variables included in our estimations. Overall, we observe that firms with foreign participation are larger, more intensive in human capital, with higher levels of operational performance, being also more concentrated in urban centers, when compared to domestic firms.

Regarding the industries entered, our results confirm expected differences between foreign and domestic entrants. Foreign entrants prefer industries where concentration is higher, where minimum efficient scale is larger, with stronger foreign presence and greater openness to external trade. Regarding the industry growth rate, the entry rates in the industry and the agglomeration in the region where firms are located, the differences were not so evident. However, the overall results suggest that, due to their intrinsic advantages, foreign entrants are usually in a better position to overcome the obstacles posed by entry barriers. A correlation matrix for the main variables included in the estimations can be found in Appendix A.II.

\subsection{Estimation results}

\subsubsection{The foreign ownership effect}

Table 5 provides our first results on the effect of foreign ownership measured by the share of firm capital held by foreign investors. Table A.III presents a summary of the results obtained

Table 3

Survival rates for domestic and foreign SMEs and LEs (Portugal, 1988-2005).

\begin{tabular}{|c|c|c|c|c|c|c|c|c|}
\hline \multirow[t]{2}{*}{ Survival time } & \multicolumn{2}{|c|}{ Domestic Firms } & \multicolumn{2}{|c|}{ Minority FF } & \multicolumn{2}{|c|}{ Majority FF } & \multicolumn{2}{|c|}{ Wholly-Owned FF } \\
\hline & SMEs & LEs & SMEs & LEs & SMEs & LEs & SMEs & LEs \\
\hline 1 & 0.8059 & 0.7957 & 0.9459 & 1.0000 & 0.9034 & 1.0000 & 0.9127 & 0.8966 \\
\hline 3 & 0.6001 & 0.7162 & 0.8188 & 0.7500 & 0.7359 & 0.9167 & 0.7927 & 0.7890 \\
\hline 5 & 0.4686 & 0.6479 & 0.7294 & 0.7500 & 0.6371 & 0.8148 & 0.6950 & 0.6216 \\
\hline 7 & 0.3790 & 0.5822 & 0.6202 & 0.7500 & 0.5774 & 0.6984 & 0.6245 & 0.6216 \\
\hline 9 & 0.3160 & 0.5433 & 0.5770 & 0.7500 & 0.5230 & 0.6984 & 0.5498 & 0.4895 \\
\hline 11 & 0.2661 & 0.4939 & 0.5339 & 0.7500 & 0.4794 & 0.5587 & 0.4980 & 0.4196 \\
\hline 13 & 0.2240 & 0.4939 & 0.4905 & . & 0.4349 & 0.5587 & 0.4481 & 0.4196 \\
\hline 15 & 0.1909 & 0.4233 & 0.4088 & . & 0.3947 & . & 0.4252 & 0.4196 \\
\hline 17 & 0.1652 & 0.4233 & 0.3577 & . & 0.3464 & . & 0.3753 & 0.4196 \\
\hline Log-Rank Test $\chi^{2}(1)$ & \multicolumn{2}{|c|}{$13.46^{* * *}$} & \multicolumn{2}{|c|}{0.10} & \multicolumn{2}{|c|}{1.21} & \multicolumn{2}{|c|}{0.08} \\
\hline Wilcoxon Test $\chi^{2}(1)$ & \multicolumn{2}{|c|}{$5.93^{* * *}$} & \multicolumn{2}{|c|}{0.05} & \multicolumn{2}{|c|}{1.74} & \multicolumn{2}{|c|}{0.12} \\
\hline
\end{tabular}

SMEs: Small and Medium Enterprises; LEs: Large Enterprises.

${ }_{* * *}^{* *}$ Significant at $5 \%$.

*** Significant at $1 \%$.

Table 4

Descriptive statistics (mean values) - Portugal, 1988-2005.

\begin{tabular}{|c|c|c|c|c|}
\hline & Domestic Firms & Minority FF & Majority FF & Wholly-Owned FF \\
\hline For. Ownership & 0.0000 & 0.2969 & 0.7264 & 1.0000 \\
\hline FF_Minority ${ }^{\mathrm{a}}$ & 0.0000 & 1.0000 & 0.0000 & 0.0000 \\
\hline FF_Majority ${ }^{\mathrm{a}}$ & 0.0000 & 0.0000 & 1.0000 & 0.0000 \\
\hline FF_Wholly Owned ${ }^{a}$ & 0.0000 & 0.0000 & 0.0000 & 1.0000 \\
\hline Age & 4.7777 & 5.8604 & 5.5523 & 5.9005 \\
\hline Size & 1.6476 & 3.2959 & 3.2432 & 3.6857 \\
\hline Firm Performance & 10.1401 & 11.0170 & 11.2076 & 11.2745 \\
\hline Human Capital & 0.0174 & 0.1054 & 0.0995 & 0.1169 \\
\hline Urban $^{\mathrm{a}}$ & 0.3680 & 0.4593 & 0.4225 & 0.4891 \\
\hline MES & 6.5954 & 6.8858 & 7.0600 & 6.9880 \\
\hline HH Index & 0.0024 & 0.0039 & 0.0035 & 0.0034 \\
\hline Industry Agglomeration & 0.1857 & 0.1584 & 0.1763 & 0.1881 \\
\hline Regional Agglomeration & 0.0743 & 0.0810 & 0.0750 & 0.0774 \\
\hline Foreign Presence in Industry & 0.1088 & 0.1344 & 0.1390 & 0.1524 \\
\hline Industry Openness & 1.9627 & 2.1910 & 2.2775 & 2.5533 \\
\hline Industry Growth & -0.0058 & -0.0133 & -0.0116 & -0.0098 \\
\hline Entry Rate & 0.0586 & 0.0549 & 0.0560 & 0.0551 \\
\hline
\end{tabular}

\footnotetext{
a Indicator variable.
} 
from the estimation of an alternative specification of the global model, after replacing the Foreign Ownership variable by three indicator variables for each type of Foreign Firms (FF): Minority, Majority or Wholly Foreign-Owned firm.

Model 1 in Table 5 shows the effect of foreign ownership on the risk of failure, without controlling for any other firm-level or industry-level characteristics. The results of these first estimations are in line with those obtained from previous firm survivor functions (Fig. 3) - unconditionally, foreign ownership decreases firm exit risk. When we consider foreign ownership measured by the three indicator variables for Minority, Majority and WhollyOwned FF, we find that, without controlling for any other observable characteristics, all the three groups of firms have about 29-36\% lower rates of hazard than domestic firms (by taking the exponents of the coefficients of model 1, in Table A.III). For the period 1983-1989, Mata and Portugal (2002) had found as well that, unconditionally, FF were $51 \%$ less prone to exit than domestic firms. However, the magnitude of the coefficients is not directly comparable because the periods of analysis are significantly different.

Model 2 adds to the Foreign Ownership variable the other firmlevel characteristics. Model 3 controls for industries' specificities. Model 4 introduces the macroeconomic control, by adding the two indicator variables for downturn periods. From these results, we conclude that when controlling for other firm and industry characteristics, and also macroeconomic conditions, the effect of foreign ownership turns out to be positively and significantly related to firm hazard. This means that, overall, during normal/ average conditions, foreign firms have higher exit rates than their domestic counterparts. Results in Table A.III show that this is true particularly for the groups of Majority FF, though the differences are rarely statistically significant.

The inclusion of indicator variables for downturn periods in model 4 also allows us to verify that firm exit is countercyclical, increasing during recessive periods. Moreover, the effect of the first downturn (1991-1994) was greater in magnitude, suggesting that the international crisis had a larger negative effect on overall firm survival, when compared to the second domestic shock. Taking the exponents of both coefficients, we see that firms' hazard increased on average by $27 \%$ during the first downturn period and by nearly $10 \%$ in the second.

With model 5, we are able to answer our central research question about the effect of foreign ownership during periods of economic slowdown. It were included the terms For.Own. ${ }^{*}$ Downturn9194 and For.Own. ${ }^{*}$ Downturn0103 in the estimation of the global model. Our results show that foreign firms suffered comparatively higher exit risks, but only when the crisis added also an international dimension. For the downturn of 1991-1994, we verify that foreign ownership increases firm exit risks even more. Results from Table A.III show that Majority FF were particularly more exposed to failure during the first downturn period, presenting about $57 \%(\exp (0.4535)=1.5738)$ higher hazard rates than domestic firms. Hence, the differences that already existed between both sets of firms were intensified during the first downturn.

Regarding the second downturn period, the coefficient of For.Own. ${ }^{*}$ Downturn0103 is negative but not statistically significant. The higher hazard rates observed during normal periods for foreign firms vanished during the 2001-2003 crisis. Hence, compared to foreign firms, domestic firms were more penalized by this second downturn. Foreign-owned firms might have resisted slightly better to that shock, possibly owing to their internal resources, networks or to the capacity to explore the international market.

Hence, overall, foreign firms may act as stabilizer agents during downturns driven by a domestic shock, if this is not accompanied by declines in international demand. Álvarez and Görg (2009) found foreign firms to have higher risk rates than domestic ones during an economic downturn, but also concluded that exportoriented multinationals were less susceptible to adverse changes in the host economy as compared to domestic market oriented multinationals. The former may have substituted exports for domestic output and hence were able to fend off negative effects and able to sustain their operations in Chile.

Therefore, the extent to which the foreignness effect matters to explain exit may, on the one hand, depend on the type of crises. If the crisis is more related to a domestic demand contraction, foreign firms may indeed overcome better the downturn. Being normally larger than domestic firms and often less reliant on the domestic market, they may switch their sales from host countries to export markets (Lipsey, 2001), and may be better able to face the adverse economic conditions. On the other hand, the type of FDI may also play a role, as horizontally- and vertically-integrated foreign firms may react differently to a shock in the host economy. While the former - by often replicating an identical production process across countries and thus sharing a substituting relationship with the parent multinational firm (e.g., Yeaple, 2003) - are expected to be more volatile and shift production back home when facing demand contractions in the host country, vertically-integrated foreign firms may, instead, be more resilient during a crisis, owing to the stabilizing role of vertical production linkages and to the complementarities established with home country production (Alfaro \& Chen, 2012; Bogach \& Noy, 2012). Unfortunately, our data do not allow the distinction between horizontally- and verticallyintegrated foreign firms, so future research should explore whether and how the type of FDI acts as a relevant channel through which foreign ownership can affect firm behavior during a crisis.

\subsubsection{Firm and industry-level determinants of firm survival}

Regarding the effect of other variables on firm survival, we observe that firm-level variables, are all statistically significant. Firm age, though weakly, exerts an inverted U-shaped effect upon exit rates; estimated coefficients suggest that firm hazards increase during the first eight years of firm life and start to decrease thereafter. Firm size, in turn, has a U-shaped effect on firm hazards; firms employing about 200 workers are estimated to have the lowest exit risks on average, while very small and very large firms face the greatest hazards. Firm performance is found to be negatively related to firm hazard.

Contrary to our expectations, human capital increases the firms' exit risk. Though surprising, such an outcome may have a reasonable explanation and similar conclusions have already been obtained by other studies for Portugal using QP database. Teixeira and Vieira (2005), based on data relative to 28 NUTs and 275 Portuguese municipalities between 1990 and1999, found that human capital intensive regions were those that, on average, had higher rates of firm failure. According to their study, hiring top educated workers may increase firm failure risk, at least in the medium-long run, since these workers tend to absorb firm total industry specific knowledge quicker than their less educated counterparts, and therefore require higher wage levels, otherwise they exit to rival firms, which may make the firm unprofitable. For USA, Acs and Armington (2009) also found puzzling results on the link between human capital and firm survival and did not discard the hypothesis that higher shares of college degrees lead to higher rates of failure among new firms, especially during recessions. Actually, better educated workers may require higher wages, which leads to increasing costs for firms. More recently, Campbell, Ganco, Franco, and Agarwal (2012) stress that employees with higher earnings (which are positively related with their education) are less likely to leave the firm relative to employees with lower earnings, but if they leave, they are more likely to create a new 
Table 5

The effect of foreign ownership (share of foreign capital in the firm). ${ }^{\mathrm{a}}$

\begin{tabular}{|c|c|c|c|c|c|}
\hline & Model 1 & Model 2 & Model 3 & Model 4 & Model 5 \\
\hline For. Ownership & $\begin{array}{l}-0.4671^{* * *} \\
(0.0947)\end{array}$ & $\begin{array}{l}0.1242^{* *} \\
(0.0621)\end{array}$ & $\begin{array}{l}0.1338^{* *} \\
(0.0614)\end{array}$ & $\begin{array}{l}0.1358^{* *} \\
(0.0626)\end{array}$ & $\begin{array}{l}0.1217 \\
(0.0798)\end{array}$ \\
\hline Age & & $\begin{array}{l}0.2902 \\
(0.1842)\end{array}$ & $\begin{array}{l}0.3143^{*} \\
(0.1841)\end{array}$ & $\begin{array}{l}0.3220 \\
(0.1843)\end{array}$ & $\begin{array}{l}0.3218^{*} \\
(0.1843)\end{array}$ \\
\hline $\mathrm{Age}^{2} / 100$ & & $\begin{array}{l}-1.7375^{*} \\
(1.0076)\end{array}$ & $\begin{array}{l}-1.9009^{*} \\
(1.0072)\end{array}$ & $\begin{array}{l}-1.9067^{*} \\
(1.0081)\end{array}$ & $\begin{array}{l}-1.9065^{*} \\
(1.0081)\end{array}$ \\
\hline Size & & $\begin{array}{l}-0.6136^{* * *} \\
(0.0136)\end{array}$ & $\begin{array}{l}-0.6002 \\
(0.0136)\end{array}$ & $\begin{array}{l}-0.6163^{* * *} \\
(0.0141)\end{array}$ & $\begin{array}{l}-0.6162^{* * *} \\
(0.0141)\end{array}$ \\
\hline $\operatorname{Size}^{2}$ & & $\begin{array}{l}0.0582^{* * *} \\
(0.0031)\end{array}$ & $\begin{array}{l}0.0570^{* * *} \\
(0.0031)\end{array}$ & $\begin{array}{l}0.0582^{* * * *} \\
(0.0032)\end{array}$ & $\begin{array}{l}0.0582^{* * * *} \\
(0.0032)\end{array}$ \\
\hline Firm Performance & & $\begin{array}{l}-0.0112 \\
(0.0051)\end{array}$ & $\begin{array}{l}-0.0112 \\
(0.0051)\end{array}$ & $\begin{array}{l}-0.0124 \\
(0.0052)\end{array}$ & $\begin{array}{l}-0.0122 \\
(0.0052)\end{array}$ \\
\hline Human Capital & & $\begin{array}{l}0.3210^{* * * *} \\
(0.0500)\end{array}$ & $\begin{array}{l}0.2884^{* * *} \\
(0.0496)\end{array}$ & $\begin{array}{l}0.2814^{* * *} \\
(0.0508)\end{array}$ & $\begin{array}{l}0.2845^{* * *} \\
(0.0507)\end{array}$ \\
\hline Urban & & $\begin{array}{l}0.1748^{* * *} \\
(0.0110)\end{array}$ & $\begin{array}{l}0.1400^{* * *} \\
(0.0148)\end{array}$ & $\begin{array}{l}0.1399^{* * * *} \\
(0.0153)\end{array}$ & $\begin{array}{l}0.1400^{* * * *} \\
(0.0153)\end{array}$ \\
\hline MES & & & $\begin{array}{l}-0.0436^{* * *} \\
(0.0068)\end{array}$ & $\begin{array}{l}-0.0640 \\
(0.0073)\end{array}$ & $\begin{array}{l}-0.0640 \\
(0.0073)\end{array}$ \\
\hline HH Index & & & $\begin{array}{l}6.1368 \\
(3.8362)\end{array}$ & $\begin{array}{l}5.1442 \\
(3.9173)\end{array}$ & $\begin{array}{l}5.0165 \\
(3.9195)\end{array}$ \\
\hline Industry Agglomeration & & & $\begin{array}{l}-0.4552 \\
(0.3796)\end{array}$ & $\begin{array}{l}-0.7698^{* *} \\
(0.3862)\end{array}$ & $\begin{array}{l}-0.7651^{* *} \\
(0.3863)\end{array}$ \\
\hline Regional Agglomeration & & & $\begin{array}{l}0.6015^{* * *} \\
(0.1602)\end{array}$ & $\begin{array}{l}0.6386^{* * *} \\
(0.1650)\end{array}$ & $\begin{array}{l}0.6374^{* * *} \\
(0.1650)\end{array}$ \\
\hline Foreign Presence in Industry & & & $\begin{array}{l}-0.7578 \\
(0.3334)\end{array}$ & $\begin{array}{l}-0.2064 \\
(0.3354)\end{array}$ & $\begin{array}{l}-0.2012 \\
(0.3355)\end{array}$ \\
\hline Industry Openness & & & $\begin{array}{l}0.0404^{* * *} \\
(0.0125)\end{array}$ & $\begin{array}{l}0.0713^{* * * *} \\
(0.0130)\end{array}$ & $\begin{array}{l}0.0715^{* * * *} \\
(0.0130)\end{array}$ \\
\hline Industry Growth & & & $\begin{array}{l}-0.2148 \\
(0.0420)\end{array}$ & $\begin{array}{l}-0.1075^{* * *} \\
(0.0419)\end{array}$ & $\begin{array}{l}-0.1070^{* *} \\
(0.0419)\end{array}$ \\
\hline Entry Rate & & & $\begin{array}{l}5.1561^{* * * *} \\
(0.3691)\end{array}$ & $\begin{array}{l}3.5316^{* * *} \\
(0.3974)\end{array}$ & $\begin{array}{l}3.5213^{* * *} \\
(0.3974)\end{array}$ \\
\hline Downturn9194 & & & & $\begin{array}{l}0.2377^{* * *} \\
(0.0187)\end{array}$ & $\begin{array}{l}0.2356^{* * *} \\
(0.0188)\end{array}$ \\
\hline Downturn0103 & & & & $\begin{array}{l}0.0916^{* * *} \\
(0.0127)\end{array}$ & $\begin{array}{l}0.0929^{* * *} \\
(0.0128)\end{array}$ \\
\hline For. Own.*Downturn9194 & & & & & $\begin{array}{l}0.2949^{* *} \\
(0.1485)\end{array}$ \\
\hline For. Own.*Downturn0103 & & & & & $\begin{array}{l}-0.1694 \\
(0.1437)\end{array}$ \\
\hline Constant & $\begin{array}{l}-3.4715^{* * *} \\
(0.0712)\end{array}$ & $\begin{array}{l}-1.4196^{* * *} \\
(0.1835)\end{array}$ & $\begin{array}{l}-1.4425^{* * *} \\
(0.1903)\end{array}$ & $\begin{array}{l}-1.2875^{* * *} \\
(0.1916)\end{array}$ & $\begin{array}{l}-1.3179^{* * *} \\
(0.1915)\end{array}$ \\
\hline Industry Dummies & YES & YES & YES & YES & YES \\
\hline Duration Dummies & YES & YES & YES & YES & YES \\
\hline $\mathrm{N}$ & 360,145 & 360,145 & 360,145 & 360,145 & 360,145 \\
\hline$\frac{\text { Log Likelihood }}{\chi^{2}}$ & $\begin{array}{l}-160,514.94 \\
1035.07^{* * *}\end{array}$ & $\begin{array}{l}-129,281.64 \\
10.622 .81^{* * *}\end{array}$ & $\begin{array}{l}-127,492.04 \\
11,332.53^{* * *}\end{array}$ & $\begin{array}{l}-127,394.48 \\
10.996 .99^{* * * *}\end{array}$ & $\begin{array}{l}-127,391.07 \\
11.002 .87^{* * *}\end{array}$ \\
\hline$\hat{\sigma}_{\mathrm{u}}$ & 2.7656 & 0.4241 & 0.3577 & 0.4505 & 0.4503 \\
\hline$\rho$ & 0.8230 & 0.0986 & 0.0722 & 0.1098 & 0.1097 \\
\hline$\chi^{2}(\rho)$ & $373.58^{* * *}$ & $35.59^{* * *}$ & $18.76^{* * *}$ & $39.00^{* * *}$ & $39.00^{* * *}$ \\
\hline
\end{tabular}

To interpret the above results in terms of odds ratios, we must take the exponent of estimated coefficients. $\rho$ measures the proportion of total unexplained variance that is contributed by individual specific effects; $\sigma_{u}$ corresponds to the standard deviation of the heterogeneity variance; $\chi^{2}(\rho)$ is the Chi-squared test for the significance of unobserved heterogeneity.

a Complementary log-logistic model with piece-wise constant hazard rates and Inverse Gaussian unobserved heterogeneity.

* Significant at $10 \%$.

Significant at $5 \%$.

Significant at $1 \%$.

venture than join another firm, which may be harmful for the source firm.

Regarding the influence of location, being located in urban centers is found to increase the risk of failure, so despite the wealth of diverse resources often found in urban areas, the intensity of competition or diseconomies of agglomeration lowers the survival prospects of firms. With respect to the effect of industry variables, higher entry rates and higher openness to trade increase the risk of exit. Higher minimum efficient scale of the industry instead reduces firm hazards. The larger the industry growth, the lower are the estimated hazard risks for firms. Firms operating in more agglomerated regions (in terms of employment) face higher exit risks. The effect arising from foreign presence is not statistically significant.
However, we must be aware that some of these variables may be endogeneous, being jointly determined with firm hazard rates and correlated with the error term. According to prior literature, firm size and firm performance are the main regressors potentially suffering from endogeneity problems (see, for instance, Blanchard, Dhyne, Fuss, \& Mathieu, 2012). In other words, there may be unobservable factors that affect firm hazard rates and that also impact on these variables. Demand shocks or a great idea for a new product are only some of the unobservable factors that may affect not only firm exit but also firm size and performance. In addition, the shadow of death phenomenon (e.g., Griliches \& Regev, 1995) may also play a role, as firm productivity or size tend to decline prior to exit, so these variables may be endogeneous with respect 
to the exit decision. Accordingly, robustness checks taking into account the potential endogeneity of these regressors must be performed.

\subsubsection{Endogeneity issues and robustness checks}

According to the literature, there is neither a standard Instrumental-Variable (IV) estimation in the context of hazard models, nor a test of instrument validity under non-linear hazard estimation (Bandick \& Görg, 2010; Bascle, 2008; Wang, 2013). Consequently, results are reliable under the assumption of instrument validity, which, so far, cannot be tested in this type of models. Even so, the use of lagged values of endogeneous covariates as instruments is a common - and less compromising practice (e.g., Blanchard et al., 2012; Girma \& Gong, 2008; Haskel, Pereira, \& Slaughter, 2007; Wang, 2013), thus offering a satisfactory alternative when the suitability of instruments is not testable.

Concerning the way to introduce IV in non-linear regressions as discrete time hazard models, this seems to be an issue still under development, particularly when the potentially endogeneous regressors are continuous (instead of binary/choice variables). Prior procedures found in similar literature typically follow one of the two most common practices: either (1) use the lagged terms of the endogeneous variables instead of their current values, assuming that contemporaneous values are affected by their lags, while these lagged terms do not correlate (or are, at least, much less correlated) with the error term (e.g., Wang, 2013); or (2) follow the typical IV methods adopted in linear models, by regressing the endogeneous variable(s) on a set of exogeneous variables - that include the exogeneous variables from the main model and additional instruments (typically, the lagged value(s) of the endogeneous variable(s)), and then introducing the fitted value of the endogeneous variable(s) from this first-step regression(s) in the original model (e.g., Bandick \& Görg, 2010; Blanchard et al., 2012). ${ }^{2}$

Due to the identified limitations, we analyze the endogeneity of firm size and performance in an exploratory manner, using the two aforementioned alternatives. However, unfortunately, when using IV approach, there seems to be no formal test to choose between the standard and the IV estimation in the context of survival models (Wang, 2013). Thus, we provide the results obtained from IV approach as a robustness test, just to compare with the baseline results (model 5 from Table 5 ). ${ }^{3}$

We report the results from our robustness tests in Table 6. In the first column we report the results for model 5, after replacing the variables Size and Firm Performance by their lagged values. This approach, though simpler, allows attenuating simultaneity bias. In the second column, we follow the typical IV method and replace both variables by their fitted value, obtained from the first stage estimation (whose results are reported in Table A.IV).

\footnotetext{
${ }^{2}$ A less conventional approach is also explored by Hyytinen and Ilmakunnas (2007) and Blanchard et al. (2012). They include the residual from the first step estimation in the original model and test the significance of the coefficient of that residual. If the corresponding coefficient is statistically significant, this may be a sign of significant endogeneity problems, confirming that the endogeneous variables should be instrumented. We have also followed this exploratory approach, which confirmed that this was the case for both variables under analysis - firm size and firm performance. The results from those additional estimations are available upon request from the authors.

3 Bandick and Görg (2010) also recognize that, hitherto, there is no formal method to choose between the two models. Even so, they suggest that the results from a standard Hausman test would be a rough indicator of whether or not the assumption of exogeneity holds. We follow their approach and compare the baseline model (model 5) with the results from IV estimation (column 2 in Table 6). The test, reported at the bottom of Table 6 , suggests that the exogeneity assumption can be rejected. In addition, the log-likelihood is higher in IV estimation. Overall, the results suggest that IV estimation results might be preferable to the baseline results.
}

Table 6

Robustness checks to the endogeneity of some regressors. ${ }^{a}$

\begin{tabular}{|c|c|c|}
\hline & 1-Year lag & IV estimation \\
\hline For. Ownership & $\begin{array}{l}0.0507 \\
(0.0848)\end{array}$ & $\begin{array}{l}0.0918 \\
(0.0886)\end{array}$ \\
\hline Age & $\begin{array}{l}0.3232 \\
(0.2027)\end{array}$ & $\begin{array}{l}0.3663^{*} \\
(0.2080)\end{array}$ \\
\hline $\mathrm{Age}^{2} / 100$ & $\begin{array}{l}-1.8601^{*} \\
(1.0511)\end{array}$ & $\begin{array}{l}-2.0917^{*} \\
(1.0787)\end{array}$ \\
\hline Size $(\S)$ & $\begin{array}{l}-0.4975^{* * *} \\
(0.0134)\end{array}$ & $\begin{array}{l}-0.5294^{* * *} \\
(0.0162)\end{array}$ \\
\hline $\operatorname{Size}^{2}(\S)$ & $\begin{array}{l}0.0495^{* * * *} \\
(0.0033)\end{array}$ & $\begin{array}{l}0.0532^{* * *} \\
(0.0037)\end{array}$ \\
\hline Firm Performance $(\S)$ & $\begin{array}{l}-0.0532 \\
(0.0059)\end{array}$ & $\begin{array}{l}-0.1032 \\
(0.0090)\end{array}$ \\
\hline Human Capital & $\begin{array}{l}0.4367^{* * * *} \\
(0.0580)\end{array}$ & $\begin{array}{l}0.5268^{* * * *} \\
(0.0606)\end{array}$ \\
\hline Urban & $\begin{array}{l}0.1295^{* * *} \\
(0.0160)\end{array}$ & $\begin{array}{l}0.1176^{* * *} \\
(0.0166)\end{array}$ \\
\hline MES & $\begin{array}{l}-0.0693^{* * * *} \\
(0.0088)\end{array}$ & $\begin{array}{l}-0.0643^{* * *} \\
(0.0091)\end{array}$ \\
\hline HH Index & $\begin{array}{l}7.5871 \\
(4.7295)\end{array}$ & $\begin{array}{l}7.9842 \\
(4.8240)\end{array}$ \\
\hline Industry Agglomeration & $\begin{array}{l}-0.0906 \\
(0.4336)\end{array}$ & $\begin{array}{l}0.0800 \\
(0.4475)\end{array}$ \\
\hline Regional Agglomeration & $\begin{array}{l}0.6986^{* * * *} \\
(0.1774)\end{array}$ & $\begin{array}{l}0.8354^{* * * *} \\
(0.1822)\end{array}$ \\
\hline Foreign Presence in Industry & $\begin{array}{c}-0.2414 \\
(0.3874)\end{array}$ & $\begin{array}{c}-0.4586 \\
(0.3974)\end{array}$ \\
\hline Industry Openness & $\begin{array}{l}0.0704^{* * * *} \\
(0.0151)\end{array}$ & $\begin{array}{l}0.0728^{* * *} \\
(0.0156)\end{array}$ \\
\hline Industry Growth & $\begin{array}{l}-0.1849 \\
(0.0480)\end{array}$ & $\begin{array}{l}-0.17722^{* * *} \\
(0.0494)\end{array}$ \\
\hline Entry Rate & $\begin{array}{l}3.9121^{* * * *} \\
(0.4677)\end{array}$ & $\begin{array}{l}4.1918 \\
(0.4793)\end{array}$ \\
\hline Downturn9194 & $\begin{array}{l}0.1631^{* * *} \\
(0.0228)\end{array}$ & $\begin{array}{l}0.1427^{* * *} \\
(0.0236)\end{array}$ \\
\hline Downturn0103 & $\begin{array}{l}0.1866^{* 2 *} \\
(0.0143)\end{array}$ & $\begin{array}{l}0.1845^{* * *} \\
(0.0147)\end{array}$ \\
\hline For. Own*Downturn9194 & $\begin{array}{l}0.4810^{* * *} \\
(0.1644)\end{array}$ & $\begin{array}{l}0.4800^{* * *} \\
(0.1700)\end{array}$ \\
\hline For. Own*Downturn0103 & $\begin{array}{l}-0.1993 \\
(0.1596)\end{array}$ & $\begin{array}{l}-0.1267 \\
(0.1621)\end{array}$ \\
\hline Constant & $\begin{array}{l}-1.4890 \\
(0.3747)\end{array}$ & $\begin{array}{l}-1.0296 \\
(0.3916)\end{array}$ \\
\hline Industry Dummies & YES & YES \\
\hline Duration Dummies & YES & YES \\
\hline $\mathrm{N}$ & 284,049 & 284,049 \\
\hline Log Likelihood & $-99,136.40$ & $-94,970.37$ \\
\hline$\chi^{2}$ & 7531.14 & 7157.55 \\
\hline$\hat{\sigma}_{\mathrm{u}}$ & 0.0824 & 0.1084 \\
\hline$\rho$ & 0.0041 & 0.0071 \\
\hline$\chi^{2}(\rho)$ & 0.01 & 0.12 \\
\hline Hausman test ( $p$-value) & - & 0.000 \\
\hline
\end{tabular}

a We extend model 5 of Table 5 to attenuate the simultaneity bias caused by some potential endogeneous regressors - explanatory variables with "( $\S)$ " in this table. In the first column, we replace each of the covariates with " $(\S)$ " by their lagged value (1-year lag). In the second column, we use instrumental variables estimation and replace those variables by the fitted value of each variable obtained from the first step equations. The results of the first stage are presented in Table A.IV.

* Significant at $10 \%$.

** Significant at $5 \%$

Significant at $1 \%$.

Results on most of the firm and industry-level covariates remain qualitatively unchanged when correcting - or at least moderating - potential problems caused by endogenous regressors. However, some new results emerge. After taking into account that firm size and performance are endogeneous and correlated with the error term, firm-level unobserved heterogeneity is no longer statistically significant. Also, the U-shaped effect of firm size on hazards now reaches its inflexion point between 145 (according to IV estimation) and 152 employees (when using lagged valued 
for the endogeneous variables), a much lower threshold than those indicated by the baseline results (about 200 employees). For the remaining variables, the correction of endogeneity did not substantially change the conclusions, though the magnitude of some effects slightly changes. The previous conclusions on the effect of foreign ownership during crises - which are the main focus of the study - remain qualitatively the same after controlling for the endogeneity of firm size and firm performance. ${ }^{4}$

Despite this analysis is still exploratory, it shows that ignoring the endogeneity of some firm-level variables may produce biased estimations. However, most of the literature addressing issues related with firm survival has been overlooking that some of the firm-level characteristics predicting exit are in fact endogeneous and jointly determined with exit decision. In view of that, further research is needed, not only regarding the effect of some (endogeneous) variables on firm survival, and moreover regarding the way to deal with such endogeneous covariates in duration models.

\section{Conclusion}

By using a unique data set with firm- and industry-level information for Portugal, this paper examines the link between foreign ownership and firm exit in Portuguese manufacturing industry over an 18-year period and during two periods of economic slowdown in particular. We investigated two main questions: if foreign affiliates have different failure rates than domestic firms during economic downturns and if the foreignness effect differs between two different economic downturns.
First, the results highlight the importance of taking firm-level heterogeneity into account when analyzing the survival patterns of firms. Unconditionally, foreign firms survive longer than their domestic counterparts. However, when controlling for other variables, the share of capital held by foreign investors is found to increase firms' hazard rates. During the downturn periods observed in the Portuguese economy, both groups of firms were severely affected, suffering higher risks of failure. Nevertheless, while in the first crisis foreign firms were markedly more affected, partially supporting the footloose argument (Hypothesis 1), in the second downturn period, the overall differences in hazard rates between domestic and foreign firms were attenuated, partially supporting Hypothesis 2.

This is the first study that systematically evaluates the foreign ownership effect upon exit during such a long time period and covering two different economic downturns. Further studies are needed also in other economies. A careful investigation of the causes behind the observed differences - taking into account, for instance, the type of FDI and MNEs' motivations - seems to be in order for a deepening of our understanding on the prospects of survival in international markets during crisis.

For the policy-maker concerned with FDI, our results on survival dynamics are not against policies stimulating inward investment. According to our results, there is no need to fear that foreign firms destabilize more than usual the host economy during economic slowdowns by immediately closing down operations.

\section{Appendix}

Table A.I

Description of variables.

\begin{tabular}{|c|c|}
\hline Variables & Description \\
\hline \multicolumn{2}{|l|}{ Main variables of interest } \\
\hline For. Ownership & Share of capital held by foreign investors in time $t$. \\
\hline FF_Minority & Dummy $=1$ if $10 \% \leq$ share of capital held in $t$ by foreign investors $<50 \%$; 0 otherwise. \\
\hline FF_Majority & Dummy $=1$ if $50 \% \leq$ share of capital held in $t$ by foreign investors $<100 \%$; 0 otherwise. \\
\hline FF_Wholly Owned & Dummy $=1$ if $100 \%$ of the capital is held in $t$ by foreign investors; 0 otherwise. \\
\hline Downturn9194 & Dummy $=1$ for the years $1991,1992,1993$ and 1994; 0 otherwise. \\
\hline Downturn0103 & Dummy $=1$ for the years 2001,2002 and 2003; 0 otherwise. \\
\hline For. Own* Downturn ${ }_{i}$ & Interaction term between foreign ownership and the dummy for the downturn $i(i=1991-1994 ; 2001-2003)$. \\
\hline FF_Minority* Downturn ${ }_{i}$ & Interaction term between FF_Minority dummy and the dummy for the downturn $i$. \\
\hline FF_Majority*Downturn ${ }_{i}$ & Interaction term between FF_Majority dummy and the dummy for the downturn $i$. \\
\hline FF_Wholly Owned *Downturn ${ }_{i}$ & Interaction term between FF_Wholly Owned dummy and the dummy for the downturn $i$. \\
\hline \multicolumn{2}{|l|}{ Firm-level controls } \\
\hline Age & Number of years since the entry of the firm. \\
\hline $\mathrm{Age}^{2} / 100$ & Squared number of years since the entry of the firm, divided by 100. \\
\hline Size & Ln(number of employees), by year. \\
\hline Size $^{2}$ & Squared value of Ln(number of employees), by year. \\
\hline Firm Performance & Operational Performance measured through the $\log$ of the ratio Firm Sales ${ }^{\mathrm{a}} /$ Firm Employment, by year. \\
\hline Human Capital & Share of workers with a college degree, by year. \\
\hline Urban & Dummy $=1$ if the firm operates in large urban areas (i.e., in the districts of Porto or Lisbon); 0 otherwise. \\
\hline \multicolumn{2}{|c|}{ Environment controls (industry and regional context) } \\
\hline MES & Median of 2-digit industry's employment, by year. \\
\hline HH Index & Herfindahl-Hirschman Index - sum of the squared share of each firm in total 2-digit industry's employment, by year. \\
\hline Industry Agglomeration & Share of 2-digit industry's employment in total Manufacturing employment, by year. \\
\hline Regional Agglomeration & Share of regional employment (NUT3) in total employment in the country, by year. \\
\hline Foreign Presence in Industry & Share of FF's employment in total 2-digit industry's employment, by year. \\
\hline Industry Openness ${ }^{\mathrm{b}}$ & Ratio 2-digit industry (Exports + Imports)/2-digit industry Gross Value Added, by year. \\
\hline Industry Growth & $\operatorname{Ln}\left(2\right.$-digit industry Employment $\left.t_{t}\right)-\operatorname{Ln}\left(2\right.$-digit industry Employment $\left.{ }_{t-1}\right)$ \\
\hline Entry Rate & Ratio (Entrants' employment in year $t / 2$-digit industry total employment in year $t$ ) \\
\hline Industry Dummies & Dummy $=1$ for each 2 -digit industry where the firm operates; 0 otherwise. \\
\hline
\end{tabular}

a Firm sales in real terms (2005 constant prices).

b Data at 2-digit industry level (ISIC rev. 2) on exports and imports come from Statistics Portugal; Gross Value Added at the industry-level was obtained from Bank of Portugal.

${ }^{4}$ Additional estimations using two year lags for both endogeneous variables

were also performed, though producing qualitatively similar results. 
Table A.II

Correlation matrix.

\begin{tabular}{|c|c|c|c|c|c|c|c|c|c|c|c|c|c|c|}
\hline & & (1) & (2) & (3) & (4) & (5) & (6) & (7) & (8) & (9) & (10) & (11) & $(12)$ & (13) \\
\hline Age & (1) & & & & & & & & & & & & & \\
\hline Size & (2) & 0.21 & & & & & & & & & & & & \\
\hline Firm Performance & (3) & 0.15 & 0.02 & & & & & & & & & & & \\
\hline Human Capital & (4) & 0.01 & 0.04 & 0.17 & & & & & & & & & & \\
\hline Foreign Ownership & (5) & 0.03 & 0.20 & 0.12 & 0.12 & & & & & & & & & \\
\hline Urban & (6) & -0.01 & 0.02 & -0.01 & 0.06 & 0.02 & & & & & & & & \\
\hline MES & (7) & -0.15 & 0.21 & -0.21 & -0.06 & 0.02 & -0.05 & & & & & & & \\
\hline HH Index & (8) & -0.04 & -0.01 & 0.15 & 0.06 & 0.04 & 0.04 & -0.01 & & & & & & \\
\hline Industry Agglomeration & (9) & -0.05 & 0.15 & -0.22 & -0.07 & 0.00 & -0.08 & 0.60 & -0.34 & & & & & \\
\hline Regional Agglomeration & (10) & -0.04 & 0.06 & -0.07 & 0.03 & 0.00 & 0.68 & 0.17 & -0.04 & 0.17 & & & & \\
\hline Industry Openness & (11) & 0.11 & -0.01 & 0.11 & 0.06 & 0.05 & -0.04 & -0.11 & 0.11 & 0.38 & -0.01 & & & \\
\hline Industry Growth & (12) & -0.03 & -0.03 & -0.01 & -0.01 & -0.00 & 0.07 & -0.11 & -0.01 & -0.11 & 0.02 & -0.08 & & \\
\hline For. Presence in Industry & (13) & 0.06 & -0.01 & 0.16 & 0.07 & 0.05 & -0.03 & -0.13 & 0.21 & 0.31 & -0.07 & 0.68 & -0.01 & \\
\hline Entry Rate & (14) & -0.03 & -0.05 & -0.03 & -0.04 & -0.02 & 0.03 & -0.18 & -0.15 & -0.16 & -0.02 & -0.15 & 0.11 & -0.21 \\
\hline
\end{tabular}

Table A.III

The effect of foreign ownership (indicator variables for Minority, Majority and Wholly-Owned FF).

\begin{tabular}{|c|c|c|c|c|c|}
\hline & Model 1 & Model 2 & Model 3 & Model 4 & Model 5 \\
\hline FF_Minority & $\begin{array}{l}-0.44966^{* *} \\
(0.2091)\end{array}$ & $\begin{array}{l}0.1392 \\
(0.1420)\end{array}$ & $\begin{array}{l}0.1537 \\
(0.1403)\end{array}$ & $\begin{array}{l}0.1604 \\
(0.1428)\end{array}$ & $\begin{array}{l}-0.0390 \\
(0.2025)\end{array}$ \\
\hline FF_Majority & $\begin{array}{l}-0.3468^{* * *} \\
(0.1311)\end{array}$ & $\begin{array}{l}0.1638 \\
(0.0905)\end{array}$ & $\begin{array}{l}0.1754 \\
(0.0897)\end{array}$ & $\begin{array}{l}0.1770^{*} \\
(0.0914)\end{array}$ & $\begin{array}{l}0.0882 \\
(0.1249)\end{array}$ \\
\hline FF_WhollyOwned & $\begin{array}{l}-0.4427^{* * *} \\
(0.1020)\end{array}$ & $\begin{array}{l}0.0849 \\
(0.0713)\end{array}$ & $\begin{array}{l}0.0942 \\
(0.0704)\end{array}$ & $\begin{array}{l}0.0957 \\
(0.0717)\end{array}$ & $\begin{array}{l}0.1165 \\
(0.0900)\end{array}$ \\
\hline Downturn9194 & & & & $\begin{array}{l}0.2377^{*+*} \\
(0.0187)\end{array}$ & $\begin{array}{l}0.2348^{* * * *} \\
(0.0188)\end{array}$ \\
\hline Downturn0103 & & & & $\begin{array}{l}0.0917^{* * * *} \\
(0.0127)\end{array}$ & $\begin{array}{l}0.0924^{* * * *} \\
(0.0128)\end{array}$ \\
\hline FF_Minority*Downturn9194 & & & & & $\begin{array}{l}0.5352 \\
(0.3572)\end{array}$ \\
\hline FF_Majority*Downturn9194 & & & & & $\begin{array}{l}0.4535^{* *} \\
(0.1966)\end{array}$ \\
\hline FF_Wholly Own*Downturn9194 & & & & & $\begin{array}{l}0.0982 \\
(0.1876)\end{array}$ \\
\hline FF_Minority*Downturn0103 & & & & & $\begin{array}{l}0.3458 \\
(0.3170)\end{array}$ \\
\hline FF_Majority*Downturn0103 & & & & & $\begin{array}{l}-0.2041 \\
(0.2472)\end{array}$ \\
\hline FF_Wholly Own*Downturn0103 & & & & & $\begin{array}{l}-0.1450 \\
(0.1614)\end{array}$ \\
\hline Industry Dummies & YES & YES & YES & YES & YES \\
\hline Duration Dummies & YES & YES & YES & YES & YES \\
\hline $\mathrm{N}$ & 360,145 & 360,145 & 360,145 & 360,145 & 360,145 \\
\hline Log Likelihood & $-160,540.95$ & $-129,280.99$ & $-127,491.23$ & $-127,393.66$ & $-127,387.93$ \\
\hline$\chi^{2}$ & $1058.28^{* * * *}$ & $10,624.49^{* * * *}$ & $11,334.77^{* * *}$ & $10,999.36^{* * *}$ & $11,011.17^{* * *}$ \\
\hline$\tilde{\sigma}_{\mathrm{u}}$ & 2.4087 & 0.4242 & 0.3577 & 0.4505 & 0.4497 \\
\hline$\rho$ & 0.7791 & 0.0986 & 0.0722 & 0.1098 & 0.1095 \\
\hline$\chi^{2}(\rho)$ & $317.46^{* * *}$ & $35.60^{* * *}$ & $18.76^{* * *}$ & $38.99^{* * *}$ & $38.86^{* * *}$ \\
\hline
\end{tabular}

a Complementary log-logistic model with piece-wise constant hazard rates and Inverse Gaussian unobserved heterogeneity. Models $1-5$ correspond to the same specifications presented in Table 5, but replacing the variable For.Ownership by the several indicator variables for Minority, Majority and Wholly-Owned FF. Accordingly, Model 1 estimates the effect of foreign ownership, without controlling for any other variables. Model 2 controls for firm-level differences. Model 3 adds industry-level variables. Model 4 includes the effect of downturns and Model 5 corresponds to the final global specification, including all variables.

* Significant at $10 \%$.

** Significant at 5\%.

Significant at $1 \%$. 
Table A.IV

First stage estimations for the endogeneous explanatory variables.

\begin{tabular}{|c|c|c|}
\hline & Firm Size & Firm Performance \\
\hline For. Ownership & $\begin{array}{l}0.1947^{* * *} \\
(0.0078)\end{array}$ & $\begin{array}{l}0.3416 \\
(0.0166)\end{array}$ \\
\hline Age & $\begin{array}{l}-0.0042^{* * * *} \\
(0.0007)\end{array}$ & $\begin{array}{l}-0.0108^{* * * *} \\
(0.0011)\end{array}$ \\
\hline Size & & $\begin{array}{l}-0.0016 \\
(0.0013)\end{array}$ \\
\hline Size $_{t-1}$ & $\begin{array}{l}0.9620^{* * *} \\
(0.0007)\end{array}$ & \\
\hline Firm Performance & $\begin{array}{l}-0.0812^{* * *} \\
(0.0011)\end{array}$ & \\
\hline Firm Performance $_{t-1}$ & & $\begin{array}{l}0.6750^{* * *} \\
(0.0029)\end{array}$ \\
\hline Human Capital & $\begin{array}{l}0.0321^{* *} \\
(0.0134)\end{array}$ & $\begin{array}{l}0.6224^{* * * *} \\
(0.0207)\end{array}$ \\
\hline Urban & $\begin{array}{l}-0.0167^{* * *} \\
(0.0019)\end{array}$ & $\begin{array}{l}-0.0310^{* * * *} \\
(0.0034)\end{array}$ \\
\hline MES & $\begin{array}{l}0.0122^{* * *} \\
(0.0011)\end{array}$ & $\begin{array}{l}0.0025 \\
(0.0023)\end{array}$ \\
\hline HH Index & $\begin{array}{l}2.0271^{* * *} \\
(0.5200)\end{array}$ & $\begin{array}{l}-0.4241 \\
(1.1171)\end{array}$ \\
\hline Industry Agglomeration & $\begin{array}{l}0.5884^{* * *} \\
(0.0530)\end{array}$ & $\begin{array}{l}-0.5106^{* * *} \\
(0.1017)\end{array}$ \\
\hline Regional Agglomeration & $\begin{array}{l}0.1278^{* * *} \\
(0.0202)\end{array}$ & $\begin{array}{l}0.1713^{* * *} \\
(0.0377)\end{array}$ \\
\hline Foreign Presence in Industry & $\begin{array}{l}-0.3922 \\
(0.0418)\end{array}$ & $\begin{array}{l}-0.1650 \\
(0.0789)\end{array}$ \\
\hline Industry Openness & $\begin{array}{l}-0.0004 \\
(0.0018)\end{array}$ & $\begin{array}{l}0.0270^{* * * *} \\
(0.0036)\end{array}$ \\
\hline Industry Growth & $\begin{array}{l}0.0089 \\
(0.0048)\end{array}$ & $\begin{array}{l}-0.0713^{* * *} \\
(0.0113)\end{array}$ \\
\hline Entry Rate & $\begin{array}{l}0.3113^{* * *} \\
(0.0552)\end{array}$ & $\begin{array}{l}0.1403 \\
(0.1083)\end{array}$ \\
\hline Downturn9194 & $\begin{array}{l}-0.0365 \\
(0.0029)\end{array}$ & $\begin{array}{l}-0.0267^{* * *} \\
(0.0061)\end{array}$ \\
\hline Downturn0103 & $\begin{array}{l}-0.0147^{* * *} \\
(0.0016)\end{array}$ & $\begin{array}{l}-0.0167^{* * *} \\
(0.0029)\end{array}$ \\
\hline Constant & $\begin{array}{l}0.8472^{* * *} \\
(0.0135)\end{array}$ & $\begin{array}{l}3.6346^{* * *} \\
(0.0344)\end{array}$ \\
\hline Industry Dummies & YES & YES \\
\hline Year Dummies & YES & YES \\
\hline $\mathrm{N}$ & 313,984 & 284,049 \\
\hline F-Statistic & $74,178.05$ & 4192.07 \\
\hline$R^{2}$ & 0.9052 & 0.5865 \\
\hline
\end{tabular}

Values in parenthesis correspond to heteroskedastic robust standard errors. The number of observations in the second equation is lower due to some missing values for firm sales, needed to compute our measure of firm performance.

* Significant at $10 \%$.

Significant at $5 \%$

**** Significant at $1 \%$.

\section{References}

Acs, Z., \& Armington, C. (2009). New firm survival and human capital. In C. Karlsson, B. Johansson, \& R. Stough (Eds.), Entrepreneurship and dynamics in the knowledge economy (pp. 125-148). UK: Routledge.

Alfaro, L., \& Chen, M. X. (2012). Surviving the global financial crisis: Foreign ownership and establishment performance. American Economic Journal: Economic Policy, 4(3), 30-55.

Álvarez, R., \& Görg, H. (2009). Multinationals and plant exit: Evidence from Chile. International Review of Economics and Finance, 18(1), 45-51.

Audretsch, D. (1995). Innovation, growth and survival. International Journal of Industria Organization, 13(4), 441-457.

Audretsch, D., \& Acs, Z. (1994). New-firm startups, technology and macroeconomic fluctuations. Small Business Economics, 6(6), 439-449.

Audretsch, D., \& Mahmood, T. (1994). The rate of hazard confronting new firms and plants in U.S. manufacturing. Review of Industrial Organization, 9(1), 41-56.

Bandick, R. (2010). Multinationals and plant survival. Review of World Economics, 146(4), 609-634.

Bandick, R., \& Görg, H. (2010). Foreign acquisition, plant survival, and employment growth. Canadian Journal of Economics, 1043(2), 547-573.

Bank of Portugal. (2004). Relatório do Conselho de Administração. Relatório e Contas.

Bank of Portugal. (2009). A Economia Portuguesa em 2008, Economic Bulletin. Spring, 15(1), 9-97.
Bascle, G. (2008). Controlling for endogeneity with instrumental variables in strategic management research. Strategic Organization, 6(3), 285-327.

Bates, T. (1990). Entrepreneur human capital inputs and small business longevity. Review of Economics and Statistics, 62(4), 551-559.

Behrman, J., \& Deolalikar, A. (1989). ... Of the fittest? Duration of survival of manufacturing establishments in a developing country. Journal of Industrial Economics, 38(2), 215-226.

Belderbos, R., \& Zou, J. (2007). On the growth of foreign affiliates: Multinational plant networks, joint ventures, and flexibility. Journal of International Business Studies, 38 , 1095-1112 http://dx.doi.org/10.1057/palgrave.jibs.8400319.

Belderbos, R., \& Zou, J. (2009). Real options and foreign affiliate divestments: A portfolio perspective. Journal of International Business Studies, 40, 600-620 http://dx.doi.org/ 10.1057/jibs.2008.108.

Bernard, A., \& Jensen, B. (2007). Firm structure, multinationals and manufacturing plant deaths. Review of Economics and Statistics, 89(2), 193-204.

Bernard, A., \& Sjöholm, F. (2003). Foreign owners and plant survival. National Bureau of Economic Research, NBER Working Paper 10039.

Bhattacharjee, A., Higson, C., Holly, S., \& Kattuman, P. (2009). Macroeconomic instability and business exit: Determinants of failures and acquisitions of UK firms. Economica, 76(301), 108-131.

Blalock, G., Gertler, P., \& Levine, D. (2005). Investment following a financial crisis: Does foreign ownership matter? Mimeo Cornell University.

Blanchard, P., Dhyne, E., Fuss, C., \& Mathieu, C. (2012). (Not so) easy come, (still) easy go? Footloose multinationals revisited. National Bank of Belgium, Working Paper No. 223.

Boeri, T., \& Bellman, L. (1995). Post-entry behaviour and the cycle: Evidence from Germany. International Journal of Industrial Organization, 13(4), 483-500.

Bogach, O., \& Noy, I. (2012). Fire-sale FDI? The impact of financial crises on foreign direct investment. Mimeo, School of Economics and Finance Working Paper No. 10/2012 New Zealand: Victoria University of Wellington.

Box, M. (2008). The deaths of firms: Exploring the effects of environment and birth cohort of firm survival in Sweden. Small Business Economics, 31(4), 379-393.

Bridges, S., \& Guariglia, A. (2008). Financial constraints, global engagement and firm survival in the United Kingdom: Evidence from micro data. Scottish Journal of Political Economy, 55(4), 444-464.

Cameron, A. C., \& Trivedi, P. K. (2005). Microeconometrics - Methods and applications. Cambridge: Cambridge University Press.

Campa, J. M. (1993). Entry by foreign firms in the U.S. under exchange rate uncertainty Review of Economics and Statistics, 75(4), 614-622.

Campbell, B. A., Ganco, M., Franco, A. M., \& Agarwal, R. (2012). Who leaves, where to and why worry? Employee mobility, entrepreneurship and effects on source firm performance. Strategic Management Journal, 33(1), 65-87.

Carreira, C., \& Teixeira, P. (2011). The shadow of death: Analyzing the pre-exit productivity of Portuguese manufacturing firms. Small Business Economics, 36(3), 337-351

Chung, C., Lu, J., \& Beamish, P. (2008). Multinational networks during times of economic crisis versus stability. Management International Review, 48(3), 279-296.

Desai, M., Foley, C., \& Forbes, K. (2004). Financial constraints and growth: Multinational and local firm responses to currency crises. National Bureau of Economic Research, NBER Working Paper 10545

Dunning, J., \& Lundan, S. (2008). Multinational enterprises and the global economy (2nd ed.). Cheltenham: Edward Elgar.

European Commission. (2005). The new SME definition. User guide and model declaration. Luxembourg: European Commission Publications, Enterprise and Industry.

Fertala, N. (2008). The shadow of death: Do regional differences matter for firm survival across native and immigrant entrepreneurs? Empirica, 35(1), 59-80.

Flamm, K. (1984). The volatility of offshore investment. Journal of Development Economics, 16(3), 231-248.

Fotopoulos, G., \& Louri, H. (2000). Location and survival of new entry. Small Business Economics, 14(4), 311-321.

Gao, T., \& Eshaghoff, T. (2004). MNCs' preferred responses to the Argentine financial crisis: A classification and empirical investigation. Latin American Business Review 5(1), 23-44.

Geroski, P., Mata, J., \& Portugal, P. (2010). Founding conditions and the survival of new firms. Strategic Management Journal, 31(5), 510-529.

Ghosal, V. (2010). Quantifying the role played by sunk capital costs in real-options models. Scottish Journal of Political Economy, 57(3), 343-358.

Girma, S., \& Gong, Y. (2008). Putting people first? Chinese state-owned enterprises' adjustment to globalization. International Journal of Industrial Organization, 26(2), 573-585.

Görg, H., \& Strobl, E. (2003a). Footloose' multinationals? The Manchester School, 71(1) $1-19$.

Görg, H., \& Strobl, E. (2003b). Multinational companies, technology spillovers and plant survival. Scandinavian Journal of Economics, 105(4), 581-595.

Griliches, Z., \& Regev, H. (1995). Productivity and firm turnover in Israeli industry: 19791988. National Bureau of Economic Research, NBER Working Paper 4059.

Haskel, J., Pereira, S., \& Slaughter, M. J. (2007). Does inward foreign direct investment boost the productivity of domestic firms? Review of Economics and Statistics, 89(3), 482-496.

Holmes, P., Hunt, A., \& Stone, I. (2010). An analysis of new firm survival using a hazard function. Applied Economics, 42(2), 185-195.

Hosmer, D., Lemeshow, S., \& May, S. (2008). Applied survival analysis - Regression modeling of time-to-event data. New Jersey: Wiley-Interscience/John Wiley \& Sons Inc.

Hougaard, P. (1995). Frailty models for survival data. Lifetime Data Analysis, 1(3), 255-273. 
Hymer, S. (1976). The international operations of national firms: A study on direct foreign investment. Cambridge: MIT Press.

Hyytinen, A., \& Ilmakunnas, P. (2007). What distinguishes a serial entrepreneur? Industrial and Corporate Change, 16(5), 793-821.

Ilmakunnas, P., \& Topi, J. (1999). Microeconomic and macroeconomic influences on entry and exits of firms. Review of Industrial Organization, 15(3), 283-301.

Jenkins, S. (2005). Survival analysis. Institute for Social and Economic Research, University of Essex. (unpublished Lecture Notes manuscript). Available at http:// www.iser.essex.ac.uk/resources/survival-analysis-with-stata-module-ec968.

Jovanovic, B. (1982). Selection and the evolution of industry. Econometrica, 50(3), 649-670.

Kalbfleisch, J., \& Prentice, R. (1980). The statistical analysis of failure data. New York: Wiley.

Kimura, F., \& Kiyota, K. (2006). Exports, FDI and productivity: Dynamic evidence from Japanese firms. Review of World Economics, 142(4), 695-719.

Kimura, F., \& Kiyota, K. (2007). Foreign-owned versus domestically-owned firms: Economic performance in Japan. Review of Development Economics, 11(1), 31-48.

Kronborg, D., \& Thomsen, S. (2009). Foreign ownership and long-term survival. Strategic Management Journal, 30(2), 207-219.

Lee, S., \& Makhija, M. (2009). Flexibility in internationalization: Is it valuable during an economic crisis? Strategic Management Journal, 30(5), 537-555.

Lehmann, A. (2002). The distribution of fixed capital in the multinational firm. IMF Staff Papers, 49(1), 136-153.

Li, J., \& Guisinger, S. (1991). Comparative business failures of foreign-controlled firms in the United States. Journal of International Business Studies, 22(2), 209-224.

Li, J., \& Rugman, A. M. (2007). Real options and the theory of foreign direct investment. International Business Review, 16(6), 687-712.

Lipsey, R. (2001). Foreign investment in three financial crisis. National Bureau of Economic Research, NBER Working Papers 8084.

Manjón-Antolín, M. C., \& Arauzo-Carod, J. (2008). Firm survival: Methods and evidence. Empirica, 35(1), 1-24.

Mata, J., \& Freitas, E. (2012). Foreignness and exit over the life cycle of firms. Journal of International Business Studies, 43, 615-630.

Mata, J., \& Portugal, P. (2002). The survival of new domestic and foreign-owned firms. Strategic Management Journal, 23(4), 323-562.
Mata, J., \& Portugal, P. (2004). Patterns of entry, post-entry growth and survival. Small Business Economics, 22(3/4), 283-298.

Narjoko, D., \& Hill, H. (2007). Winners and losers during a deep economic crisis: Firmlevel evidence from Indonesian manufacturing. Asian Economic Journal, 21(4), 343368.

Özler, S., \& Taymaz, E. (2004). Does foreign ownership matter for survival and growth? Dynamics of competition and foreign direct investment. Economic Research Center, Working Paper 04/06.

Singer, J., \& Willett, J. (1993). It's about time: Using discrete-time survival analysis to study duration and the timing of events. Journal of Educational Statistics, 18(2), 155-195.

Stinchcombe, F. (1965). Social structure and organizations. In J. March (Ed.), Handbook of organizations (pp. 142-193). Chicago: Rand McNally.

Taymaz, E., \& Özler, S. (2007). Foreign ownership, competition and survival dynamics. Review of Industrial Organization, 31(1), 23-42.

Teixeira, A., \& Vieira, P. (2005). Capital humano, falências empresariais e produtividade. Uma análise empírica das regiões Portuguesas. Estudos Regionais, 7, 5-18.

Van Beveren, I. (2007). Footloose multinationals in Belgium? Review of World Economics, 143(3), 483-507.

Varum, C., \& Rocha, V. C. (2011). Do foreign and domestic firms behave any different during economic slowdowns? International Business Review, 20(1), 48-59.

Varum, C., \& Rocha, V. C. (2012). The effect of crises on firm exit and the moderating effect of firm size. Economics Letters, 114(1), 94-97.

Wang, Y. (2013). Exposure to FDI and new plant survival: Evidence in Canada. Canadian Journal of Economics, 46(1), 46-77.

Yeaple, S. R. (2003). The complex integration strategies of multinationals and cross country dependencies in the structure of foreign direct investment. Journal of International Economics, 60(2), 293-314.

Zaheer, S. (1995). Overcoming the liability of foreignness. The Academy of Management Journal, 38(2), 341-363.

Zaheer, S., \& Mosakowski, E. (1997). The dynamics of the liability of foreignness: A global study of survival in financial services. Strategic Management Journal, 18(6), 439-464. 